\title{
SEKURYTYZACJA MIGRACJI W BEZPIECZEŃSTWIE KULTUROWYM EUROPY ${ }^{1}$
}

\author{
Agata Wiktoria Ziętek \\ Uniwersytet Marii Curie-Skłodowskiej w Lublinie \\ Wydział Politologii, Zakład Stosunków Międzynarodowych \\ e-mail: wiktoriazietek@gmail.com
}

\begin{abstract}
Streszczenie. Sekurytyzacja to intersubiektywny i intertekstualny proces włączania określonych tematów do sfery bezpieczeństwa. Tym samym opisuje jego dynamikę, wpływając na definiowanie sytuacji, zagrożeń oraz podejmowanie działań. Sekurytyzacja definiowana jako akt mowy opiera się na założeniu, że za pomocą języka można nie tylko przekazywać informacje, ale również tworzyć fakty społeczne. Jest to nie tylko prosty przekaz. Ważne jest to czemu wypowiedź ma służyć, jak dany fakt zostanie przedstawiony, przez kogo, do kogo i w jakiej sytuacji. Włączanie określonych tematów do sfery bezpieczeństwa w procesie sekurytyzacji jest dowodem na to, że rzeczywistość jest konstruktem społecznym, w którego tworzeniu język i obraz odgrywają istotną rolę. W Europie coraz silniejszy jest strach przed 'innymi'. Jest on konsekwencją dynamiki i niespotykanej skali przepływów ludzkich. To poczucie zagrożenia jest również konsekwencją skutecznego procesu sekurytyzacji migracji. W debacie politycznej i społecznej coraz częściej pojawiają się pytania o przyszłość Europy. O to jak procesy migracyjne zmienią oblicze kulturowe Europy? Czy imigracja zagraża tożsamości kulturowej Europy?
\end{abstract}

Słowa kluczowe: migracja, kryzys migracyjny w Europie, sekurytyzacja, desekurytyzacja

${ }^{1} \mathrm{Na}$ temat sekurytyzacji pisałam w kontekście bezpieczeństwa kulturowego, traktując ją obok emancypacji jako kategorię pomocną przy ontologicznym definiowaniu bezpieczeństwa. Zob.: Ziętek A. W., Kategoria sekurytyzacji w bezpieczeństwie kulturowym, Stosunki Międzynarodowe 2011, t. 44, nr 3-4, Ziętek A. W., Bezpieczeństwo kulturowe w Europie, UMCS, Lublin 2013, Ziętek A. W., Pułapki bezpieczeństwa kulturowego, [w:] G. Michałowska, J. Nakonieczna, H. Schreiber (red.), Kultura w stosunkach międzynarodowych, tom 2, Pułapki kultury, WUW, Warszawa 2014; Ziętek A. W., Sekurytyzacja islamu w Europie, [w:] E. Stadtmüller, Ł. Fijałkowski (red.), Normy, wartości i instytucje we wspótczesnych stosunkach międzynarodowych, Rambler, Warszawa 2015, Ziętek A. W., Sekurytyzacja - proces intersubiektywnej komunikacji, [w:] E. Maj, E. Podgajna, A. Szwed-Walczak, Ł. Jędrzejski (red.), Komunikowanie polityczne, UMCS, Lubin 2017. 


\section{WSTĘP}

Zagrożenia bezpieczeństwa kulturowego są konsekwencją negatywnych zmian w środowisku kulturowym państw, będących pochodną dynamiki środowiska międzynarodowego oraz procesów na poziomie wewnętrznym. Wywołują one poczucie strachu i niepewności. Na poziomie środowiska międzynarodowego źródłem niepewności jest proces horyzontalnej rywalizacji kultur. Wiąże się on z takimi obiektywnymi procesami jak: globalizacja i migracja. Oba procesy wywołują silne emocje, zarówno pozytywne, jak i coraz częściej negatywne. Proces globalizacji wpływa również na coraz większa mobilność osób. W Europie coraz silniejszy jest strach przed 'innymi'. Jest on konsekwencją dynamiki i niespotykanej skali przepływów ludzkich. To poczucie zagrożenia jest również konsekwencją skutecznego procesu sekurytyzacji migracji. W debacie politycznej i społecznej coraz częściej pojawiają się pytania o przyszłość Europy. O to jak procesy migracyjne zmienią oblicze kulturowe Europy? Czy imigracja zagraża tożsamości kulturowej Europy?

Celem mojego artykułu jest pokazanie jak procesy migracyjne są sekurytyzowane w kulturowym wymiarze bezpieczeństwa w Europie. W pierwszej części artykułu dokonam krótkiej charakterystyki procesów migracyjnych do Europy, następnie przedstawię proces sekurytyzacji migracji oraz sekurytyzacji tożsamości, odwołując się do praktyki sekurytyzacji 'Innego' w debacie politycznej wybranych państw. Następnie przeanalizuję siłę pozycjonalną i performatywną podmiotów sekurytyzacji i w zakończeniu zwrócę uwagę na ich skuteczność.

\section{MIGRACJE W EUROPIE}

Procesy migracyjne nie są zjawiskiem nowym, jednak ich obecna skala i dynamika jest wcześniej niespotykana. Według danych Międzynarodowej Organizacji ds. Migracji w 2015 roku liczba migrantów na świecie przekroczyła 244 miliony i było to o ponad dziesięć milionów więcej niż w roku $2013 .{ }^{2} \mathrm{Te}$ liczby przekroczyły przewidywane wcześniej scenariusze. Jednocześnie jesteśmy świadkami największej od czasów II wojny światowej liczby migrantów przymusowych, w tym uchodźców i osób wewnętrznie przesiedlonych. W państwach UE w 2015 r. mieszkało 34,3 mln osób urodzonych poza nią oraz 18,5 mln osób, które urodziły się w innym państwie członkowskim UE niż ich aktualne państwo zamieszkania. ${ }^{3}$ Ponad $60 \%$ przybyłych w 2015 roku osób do UE to uchodźcy z objętych wojną domową Syrii, Erytrei i Afganistanu. Inni pochodzą z Libii, Sudanu, Pakistanu, Nigerii, Somalii czy Iraku. I choć w skali globu 1 na 7 osób

2 IOM Global Migration Trends Factsheet, http://blog.iom.pl/iom-global-migration-trends-factsheet-2015/, [dostęp, 16.04.2017].

3 Statystyki dotyczące migracji i populacji migrantów, http://ec.europa.eu/eurostat/statistics -explained/index.php/Migration_and_migrant_population_statistics/pl, [dostęp, 16.04.2017]. 
stanowią migranci lub osoby przesiedlone to w przeliczeniu na mieszkańca, liczba imigrantów z Afryki Północnej i Bliskiego Wschodu, która dotarła do UE, jest w praktyce niezauważalna i wynosi nieco powyżej 1 osoby na 1000 obywateli UE. ${ }^{4}$ Problem związany z napływem fali imigrantów czy uchodźców do UE nie leży więc w liczbach bezwzględnych. Chodzie głównie o ich rozlokowanie w poszczególnych państwach. Czy też przepływ imigrantów w określonych kierunkach geograficznych. Należy również zaznaczyć, że fale migracyjne do Europy okresowo się nasilają, co należy wiązać z wydarzeniami geopolitycznymi. W latach 90. procesy migracyjne wiązały się z wojną na Bałkanach czy upadkiem Związku Radzieckiego oraz wojną w Czeczenii. Wówczas (1992 r.) w Niemczech złożono prawie 440 tys. wniosków o azyl, a Polska zaczęła przyjmować czeczeńskich uchodźców z Federacji Rosyjskiej, w skali kilku tysięcy rocznie w drugiej połowie lat $90 . \mathrm{XX} \mathrm{w}^{5}$

Do przyczyn migracji zalicza się wiele czynników wśród nich rozwój technologiczny. I nie chodzi tyko o stworzenie warunków do przemieszczania się na dalekie odległości. Procesom migracji towarzyszy globalizacja komunikacji, co skutkuje globalizacją migracji. Ludzie będąc od siebie daleko, mogą się łatwo porozumiewać. Dostęp do telefonów komórkowych, Internetu pomaga w szybkiej komunikacji z rodziną, znajomymi. Pozwala na szybkie przekazywanie informacji, chociażby o tym czego można się spodziewać po dotarciu na miejsce. ${ }^{6}$ I choć migranci z Afryki Północnej i Bliskiego Wschodu chcą przede wszystkim uciec przed prześladowaniami i wojną, większość z nich ma preferencje dotyczące celu podróży. Jest to z reguły kilka państw Europy Zachodniej, głównie Niemcy, Wielka Brytania i państwa skandynawskie, ze względu na to, że mogą one zapewnić godziwe warunki życia. Ponadto nierzadko znajdują się tam już krewni, bądź znajomi migrujących (rys. 1,2). Należy jednak pamiętać, że większość uchodźców trafia do państw, które nie są w stanie zagwarantować im bezpieczeństwa, jak chociażby do Jordanii. Państwo to odgrywa rolę bufora między Izraelem a Irakiem, Syrią a Arabią Saudyjską. Samo borykając się z wieloma problemami, stało się schronieniem dla Syryjczyków uciekających przed wojną domową, udzielając schronienia ok. 685 tyś. uchodźcom, przy populacji 6,5 mln. Tym samym zajmuje drugie po Libanie miejsce pod względem liczby uchodźców na 1000 mieszkańców (rys.3).

Do innych czynników należy zaliczyć dysproporcje rozwojowe występujące między różnymi regionami świata, sytuację polityczną, zmiany klimatu czy uwarunkowania kulturowe (występujący w danym państwie sposób życia).

Jak podkreśla Anna Badkhen współczesna migracja wiąże się nie tylko z dyslokacją ludzi, ale również jest to dyslokacja empatii, współczucia, god-

4 Niekontrolowane migracje do Unii Europejskiej - implikacje dla Polski, P. Sasnal (red.), PISM, Warszawa 2015, URL: https://www.pism.pl/files/?id_plik=20992, [dostęp, 16.04.2017].

5 Ibidem, s. 11.

6 A. Badkhen, The New (Re)Order, "Foreign Policy" 2016, 26 January. 
ności. ${ }^{7}$ Problem Europy polega na tym, że z jednej strony współczujemy, ale z drugiej strony nie ufamy migrantom/uchodźcom. W dużej mierze „wolimy” aby fala migracji nie dotarła do nas. Ba, Europa jest w stanie zapłacić innym, aby przyjęli uchodźców do siebie. Co potwierdza porozumienie z 2016 r., między Turcją i UE, zgodnie z którym w zamian za pomoc finansową i polityczne korzyści Turcja będzie przyjmować odesłanych z Europy migrantów, którzy nielegalnie dotarli tam przez Morze Egejskie. ${ }^{8}$

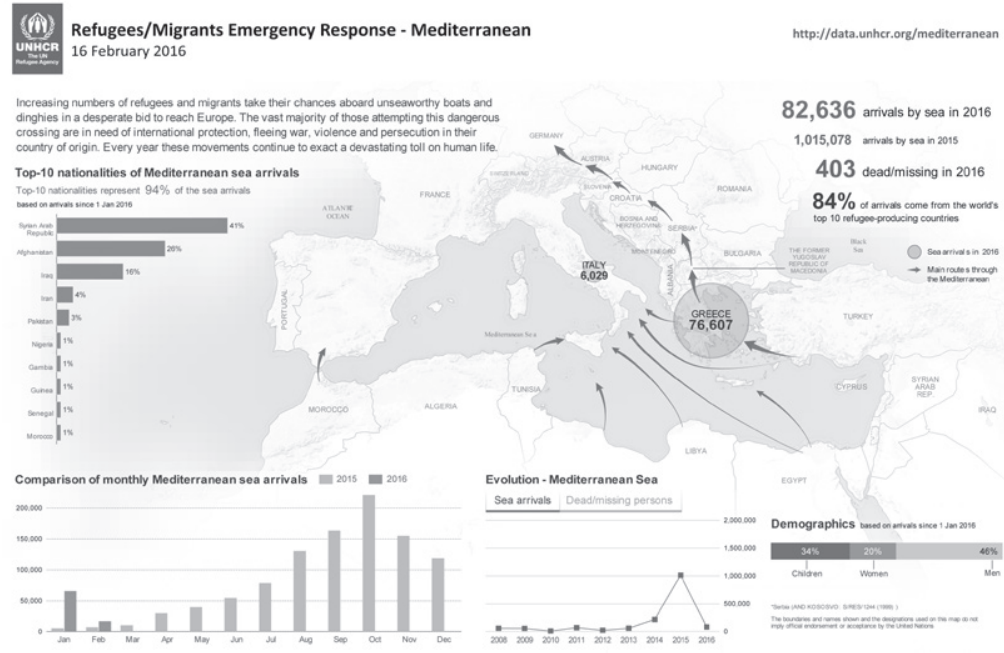

Rysunek 1. Uchodźcy - główne kierunki

Źródło: Reliefweb, URL: http://reliefweb.int/report/greece/refugeesmigrants-emergency-responsemediterranean-16-february-2016, [dostęp, 16.04.2017].

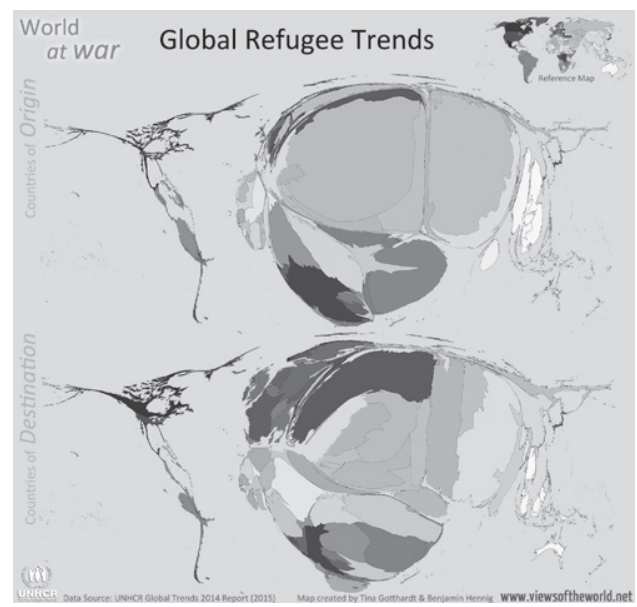

Rysunek 2. Główne kierunki migracji i państwa pochodzenia

Źródło: World at war. Global refugee trends, http://www.viewsoftheworld.net/?p=4541, [dostęp 16.04.2017]

\section{Ibidem.}

8 Turcja przyjęła z powrotem 20 odesłanych z UE migrantów, http://www.tvn24.pl. 


\begin{tabular}{|l|}
\hline $50-574$ \\
\hline $575-2,049$ \\
$2,050-3,509$ \\
\hline $3,510-9,254$ \\
\hline $9,255-14,819$ \\
$14,820-39,294$ \\
\hline $39,295-97,609$ \\
\hline
\end{tabular}

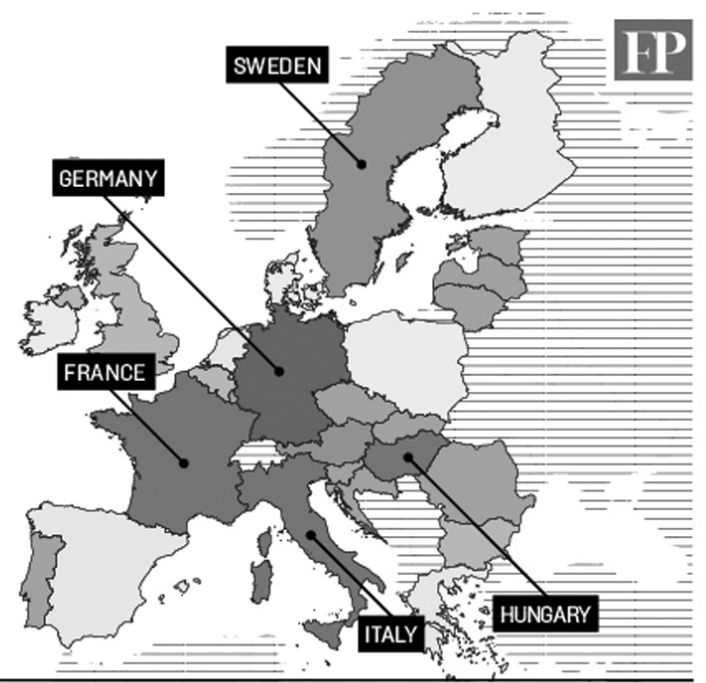

DATA: EUROSTAT, JANUARY-APRIL 2015

Rysunek 3. Główne kierunki imigracji

Źródło: Europe's Migrant Crisis By the Numbers, http://foreignpolicy.com/2015/09/03/europes-migrantcrisis-by-the-numbers/, [dostęp, 16.04.2017].

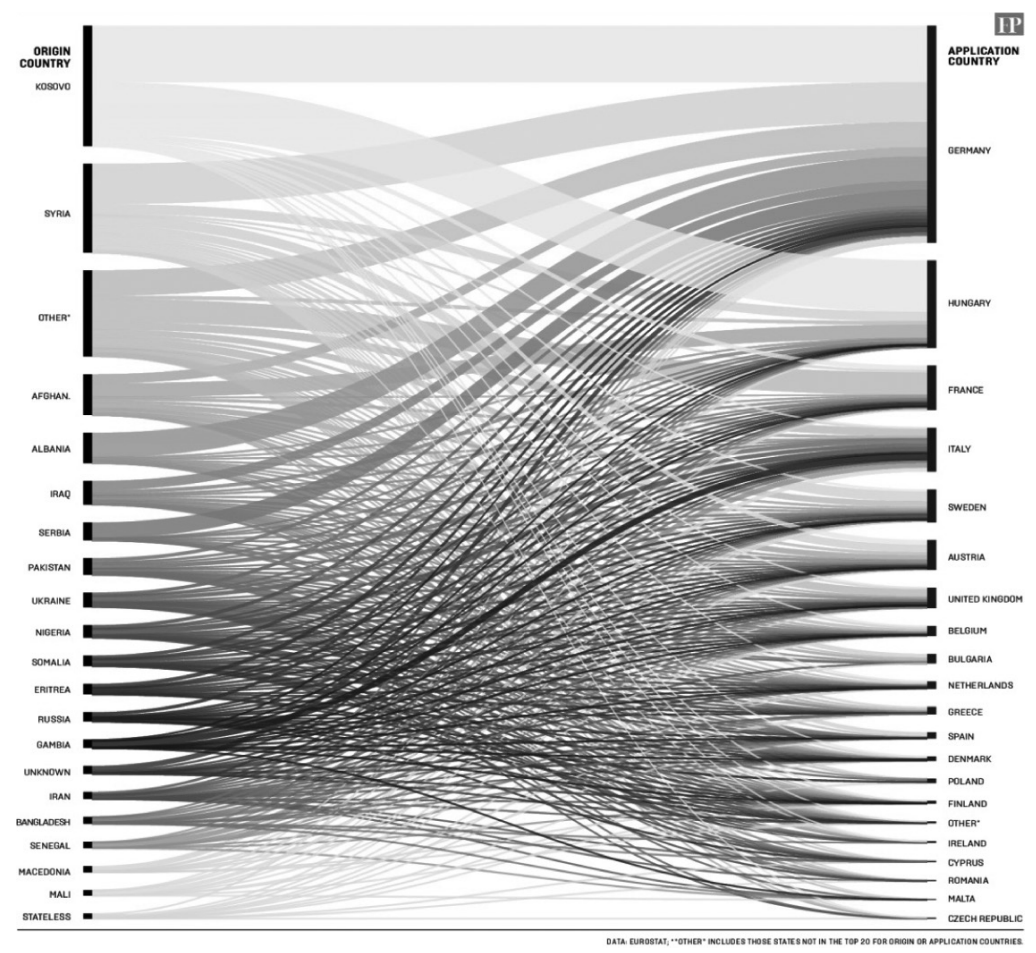

Rysunek 4. Uchodźcy skala przepływów

Źródło: Europe's Migrant Crisis By the Numbers, http://foreignpolicy.com/2015/09/03/europes-migrantcrisis-by-the-numbers/, [dostęp, 16.04.2017]. 


\section{і

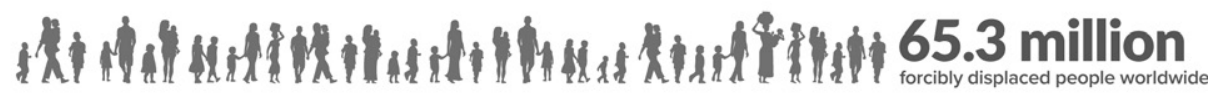 In thit think 21.3 million Mitl 10 million \\ 16.1 million under UNHCR mandate
5.2 million Palestinian refugees registered by UNRWA}

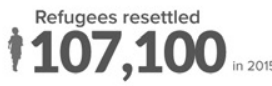

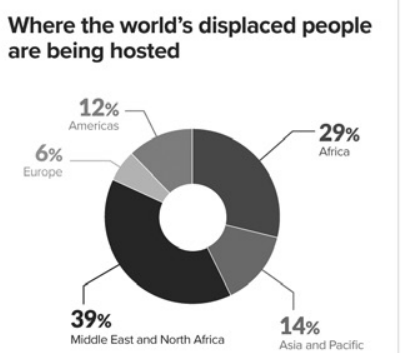

$53 \%$ of refinges wortwide

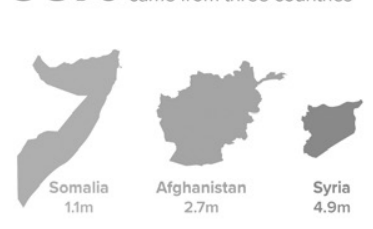

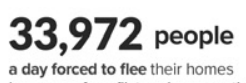

a day forced to flee their homes

\section{0,800 staff \\ UNHCR employs 10,800 staft (as of 31 December 2016)}


elementach: obiekcie odniesienia (referent object), podmiocie sekurytyzacji (securitizing actor) i podmiotach funkcjonalnych (functional actors), które mają faktyczny wpływ na percepcję bezpieczeństwa. ${ }^{10} \mathrm{~W}$ procesie sekurytyzacji istotne jest wyznaczenie obiektu odniesienia, może to być: suwerenność, tożsamość, terytorium oraz kompetentnego przywódcy, który wskaże egzystencjalne zagrożenia dla tego obiektu. ${ }^{11}$ Zatem proces ów polega na tym, że temat zostaje przedstawiony przez określony podmiot jako zagrożenie. Przekaz jest kierowany do odbiorcy, który na niego reaguje - pozytywnie - zgadza się z argumentacją, lub negatywnie - nie zgadza się. Zgoda jest równoznaczna z podejmowaniem działań, w tym z sięganiem po środki nadzwyczajne. Proces sekurytyzacji jest zatem procesem komunikacji i negocjacji, który służy osiągnięciu określonych celów. ${ }^{12}$

Należy przypomnieć, że Ole Wœver, który wprowadził kategorię sekurytyzacji do badań bezpieczeństwa, definiował ją jako ,akt mowy” (speech act). Według niego pozycjonuje się dzięki niemu konkretne zagadnienie w kategoriach zagrożeń egzystencjalnych. Zatem, można powiedzieć, że akt mowy niejako powołuje zagrożenia do życia. Teoria aktów mowy opiera się na spostrzeżeniu, że za pomocą języka można nie tylko przekazywać informację, ale tworzyć fakty społeczne. Oznacza to, że są wypowiedzi, które nie tylko opisują świat, ale go tworzą. O. Wœver swoją koncepcję aktów mowy zapożyczył od Johna L. Austina, językoznawcy i filozofa języka, który zaproponował podział aktu mowy na trzy części. ${ }^{13}$ Po pierwsze, lokucja, czyli tworzenie i artykułowanie wypowiedzi. Po drugie, illokucja, która wiąże się z intencją wypowiedzi. Mogą tu być stosowane różne narzędzia, takie jak obietnice, ostrzeżenia czy zastraszanie. Po trzecie, perlokucja, której celem jest wywołanie u odbiorcy określonego wrażenia, reakcji emocjonalnej, co stworzy możliwość osiągnięcia zamierzonego skutku, czyli przekonania o prawdziwości wypowiedzi. Tym samym akt mowy to nie tylko prosty przekaz, komunikat. Istotne jest to czemu ma on służyć, kto go artykułuje i do kogo jest skierowany. Jak podkreślał O. Wœver nie tyle ważny jest wymiar prawdziwości, co wymiar trafności. W związku z tym nie jest istotne czy zagrożenie istnieje obiektywnie, ale to jak zostanie przedstawione, przez kogo i za pomocą jakich argumentów. ${ }^{14}$

${ }^{10}$ B. Buzan, O. Wœver, J. de Wilde, Securuty, A New Framework for Analysis, Boulder 1998, s. 36 .

${ }^{11}$ Zob.: B. Buzan, O. Wover, Regions and Powers: The Structure of International Security, Cambridge University Press 2003, s. 491; B. Buzan, O. Wœver, J. de Wilde, Security, A New Framework for Analysis, Boulder 1998.

${ }^{12}$ Warto jednocześnie podkreślić, że często sekurytyzacja jest definiowana w sposób uproszczony, tym samym wyłączona jest ze swego pierwotnego kontekstu i wykorzystywana celem wskazania, że coś staje się przedmiotem debaty o bezpieczeństwie. Tym samym nie oznacza działań performatywnych, a ma charakter deskryptywny.

${ }^{13}$ Zob. Austin J.L., Mówienie i poznawanie, PWN, Warszawa 1993.

${ }^{14} \mathrm{O}$, Wœver, Societal Security, state security and internalization, [w:] O. Wæver, B. Buzan, M. Kelstrup, P. Lemaitre (red.), Identity, Migration and New Security Agenda in Europe, Londyn 1993, s. 23. 
Sekurytyzacja oznacza faktycznie, że problemy mogą być niejako powoływane od życia, nie koniecznie muszą istnieć obiektywnie. Jeszcze w latach 70. XX wieku Daniel Frei zwrócił uwagę na to, że bezpieczeństwo należy analizować uwzględniając zarówno wymiar obiektywny jak i subiektywny. ${ }^{15}$ Obiektywny oznacza występowanie zagrożeń obiektywnie lub ich bark. Subiektywny wymiar zaś wiąże się ze sferą świadomości o ich występowaniu (np. u decydentów) lub jej barku. Uwzględniając powyższe zaproponował cztery sytuacje bezpieczeństwa: stan bezpieczeństwa, braku bezpieczeństwa, fałszywego bezpieczeństwa i obsesji. Skoncentruję się w tym miejscu na omówieniu dwóch sytuacji: bezpieczeństwa fałszywego i stanu obsesji, bowiem w dwóch pozostałych mamy do czynienia ze zgodnością stanu obiektywnego ze stanem świadomości.

Po pierwsze, fałszywe bezpieczeństwo, charakteryzuje się tym, że obiektywne istnienie zagrożeń nie jest równoznaczne z podejmowaniem działań. Wówczas ośrodek decyzyjny nie ma świadomości występowania zagrożeń, co może być skutkiem braku informacji lub nieprawidłowości w jej obiegu. Szczególnie jest to widoczne w sytuacji kryzysowej, kiedy decydenci mają problem z nadmiarem informacji, co może wpływać na ich zrozumienie i przeanalizowanie. Również decydenci mogą świadomie redukować źródła informacji, tym samym eliminując szumy informacyjne. W efekcie może dojść do błędnego definiowania sytuacji, tym bardziej, że niejednokrotnie decydenci mają skłonność, szczególnie w sytuacjach kryzysowych, do przyjmowania nadchodzących informacji przez pryzmat akceptowanych teorii, schematów i wyobrażeń. Co sprawia, że selekcjonują i interpretują informacje w taki sposób, który wzmacnia ich wcześniejsze, przedkryzysowe wyobrażenia o rzeczywistości. ${ }^{16}$

Drugą sytuacją jest stan obsesji. Charakteryzuje się on tym, że przy obiektywnym barku zagrożeń podejmuje się działania jakby zagrożenia istniały. Zatem w tej sytuacji zagrożenia istnieją przede wszystkim w świadomości decydentów, czy społeczeństw. Tym samym dążą oni do tego aby przekonać o ich istnieniu innych, oraz o konieczności podjęcia działań, których celem będzie ich eliminacja. Dobrym przykładem może być referendum w Wielkiej Brytanii dotyczące wyjścia z Unii Europejskiej. Społeczeństwo Wielkiej Brytanii 23 czerwca 2016 r. wypowiedziało się za. Należy podkreślić, że kampania przedreferendalna zwolenników opuszczenia UE, w dużej mierze była budowana wokół nastrojów antyemigracyjnych. Było to ewidentne granie na emocjach i nastrojach, podsycanych dodatkowo kondycją gospodarczą Wielkiej Brytanii, sytuacją na rynku pracy i skalą imigracji, związaną z ostatnim kryzysem imigracyjnym (2015 r.)

${ }^{15}$ Zob. D. Frei, Sicherheit. Grundfrgen der Weltpolitik, Verlag W. Kohlhammer, Stuttgart 1977, cyt. za R. Zięba, Kategoria bezpieczeństwa w nauce o stosunkach międzynarodowych, [w:] D. B. Bobrow, E. Haliżak, R. Zięba (red.), Bezpieczeństwo narodowe i międzynarodowe u schytku XX wieku, Warszawa 1997.

${ }^{16}$ Zob. Z. J. Pietraś, Decydowanie polityczne, PWN, Warszawa 1998, s. 397. 
w Europie. ${ }^{17}$ Należy podkreślić, że w państwie tym od lat obserwowany był proces sekurytyzacji migracji. Tym samym narracja była dość uproszczona, wyjście z UE spowoduje koniec problemów z falą imigrantów.

Zagadnienie to poruszał Stuart Croft w swojej książce Securitizing Islam. Identity and the Search for Security. ${ }^{18}$ Zwracał on przede wszystkim uwage na proces sekurytyzacji islamu w Wielkiej Brytanii. Niemniej jednak sekurytyzacja dotyczy też generalnie imigrantów, w tym z Polski.

S. Croft podkreślał znaczenie tożsamości, konstruowanej w procesie sekurytyzacji. Wiąże się ona z pewnym aktem autoidentyfikacji - naszym stosunkiem do samego siebie. Jest również definicją siebie w odniesieniu do innych, a czasem przeciw innym. Jest zjawiskiem dynamicznym, zaś jej elastyczność i przetrwanie zależą od równowagi między jej ochroną, z jednej strony a otwartością na inne wpływy, z drugiej. Tożsamość określa źródła norm i wartości, zasięg ich obowiązywania oraz wpływa na zakres racjonalności. Służy również określeniu przestrzeni, wewnątrz której będziemy dokonywać i oceniać nasze indywidualne wybory. S. Croft zaproponował różne typy tożsamości/,inności” kreowane w procesie sekurytyzacji. Są to: tożsamość radykalnego innego, kogoś kto może być zagrożeniem dla naszej egzystencji. Jest on często przedstawiany jako monstrum. Narracji tej towarzyszy często proces dehumanizacji i stosowanie zabiegu przeciwstawienia my-oni. Inny jest zły, nieracjonalny, nienormalny, szalony, chory, prymitywny, groźny. My zaś jesteśmy dobrzy, racjonalni, normalni, zdrowi, spójni, przewidywalni. Warto w tym miejscu przypomnieć, że wielu obywateli Polski popiera retorykę eurosceptyków, ulegając dyskursowi, który podkreśla niebezpieczeństwo przed zalewem migrantami. Kolejną tożsamością, jest hierarchiczna inność. Inni niby są nami, ale jednocześnie ze względu np. na uwarunkowania historyczne, kulturowe, religijne dzieli ich od nas dystans. Ta tożsamość jest również przypisywana Polakom, mieszkającym w Wielkiej Brytanii. Kolejnym typem jest inność czasowa (temporal otherness). Ten typ tożsamości w kontekście Europy był również opisywany przez Ole Wœvera. ${ }^{19}$ Inność ma tu charakter transgeneracyjny. Zagrożeniem zaś są zachowania współczesnych, porównywalne do tych jakie miały miejsce w przeszłości. Dotyczy to chociażby procesu politycznej radykalizacja w Europie.

O sukcesie kreowania tożsamości w procesie sekurytyzacji świadczą sukcesy partii, które bazują na sentymentach narodowych i antyimigracyjnych. We wrześniu 2015 r. w Austrii w wyborach lokalnych Wolnościowa Partia Austrii (FPO) zdobyła 30\% poparcia w Górnej Austrii. W uważanym za liberalny Wiedniu partia

${ }_{17}$ Zob. S. Tilford, Britain, immigration and Brexit, CER Bulletin, Issue 105, Dec. 2015/Jan. 2016, https://www.cer.org.uk/sites/default/files/bulletin_105_st_article1.pdf, również http://www. migrationobservatory.ox.ac.uk/projects/brexit, [dostęp, 10.07.2016].

${ }^{18} \mathrm{~S}$. Croft, Securitizing Islam. Identity and the Search for Security, Cambridge University Press, Cambridge 2012, ss. 73-93.

${ }^{19}$ O. Wœver, European Security Identities, “Journal of Common Market Studies” 1996, vol. 34, nr 1, s. 103-132. 
ta odnotowała zaś rekordowe 32,4\% głosów poparcia. Przewodniczący FPO Heinz-Christian Strache (współpracownik Jorga Haidera) domagał się wzmocnienia kontroli na granicach, preferencyjnego traktowania chrześcijańskich migrantów i obrony „zachodniego charakteru Austrii”. Twierdził, że na granicy austriackiej powinno stanąć ogrodzenie, by powstrzymać napływ migrantów. ${ }^{20}$ Nacjonaliści triumfowali także w 2015 r. w Danii. Koalicja ugrupowań prawicowych odsunęła od władzy socjaldemokratów, a wchodząca w jej skład Duńska Partia Ludowa osiągnęła drugi wynik w wyborach parlamentarnych. Obecny (od 2015 r.) premier Danii Lars Løkke Rasmussen, wywodzący się z partii o liberalnym profilu politycznym Venstre, również negatywnie wypowiadał się w kwestii migracji, co niewątpliwie przysporzyło poparcia jego ugrupowaniu, tworzącemu w 2016 r. koalicje rządową. Zapowiadał szybkie zaostrzenie przepisów dla chcących osiedlić się w Danii imigrantów. Proponował też wprowadzenie opłat dla cudzoziemców korzystających z duńskiej służby zdrowia, czy też konfiskatę mienia. ${ }^{21}$ W 2015 roku w Finlandii Partia Finów (Perussuomalaiset) znana wcześniej jako Prawdziwi Finowie, po wyborach parlamentarnych uzyskała trzecią lokatę, z poparciem na poziomie $17,6 \%$, tym samym po raz pierwszy w historii weszła do rządu. We Francji Front Narodowy w pierwszej turze wyborów regionalnych zdobył wysokie $28 \%$ poparcie, chociaż ostatecznie przegrał w „dogrywce” na korzyść ugrupowania Republikanów N. Sarkozego. Niemniej jednak liderka partii Marine Le Pen weszła do drugiej tury wyborów prezydenckich w 2017 roku.

S. Croft wyróżnia jeszcze jedną tożsamość konstruowaną w procesie sekurytyzacji - żałosnego innego. Żałosny jest groszy, śmieszny, ale też może być groźny. Taka inność może funkcjonować nawet w sytuacji gdy jest przypisywana nielicznym obywatelom w danym państwie. Przecież w wielu państwach europejskich odsetek wyznawców islamu, czy imigrantów jest niewielki, co nie zmienia faktu, że występują tam silne postawy ksenofobiczne. Można sobie oczywiście postawić pytanie na ile ta inność jest stanem obiektywnym, a na ile stanem umysłu, wyobrażeń?

Proces sekurytyzacji 'innego' jest również obecny w politycznej debacie w Polsce. Szczególnie mocno temat został uwypuklony w trakcie dyskusji w sprawie uchodźców. Wówczas swoje wątpliwości dotyczące przyjęcia uchodźców wyraził prezes PiS Jarosław Kaczyński, który w trakcie jednego ze spotkań w 2015 roku przekonywał, że sprawą imigrantów powinien zainteresować się minister zdrowia. Jak mówił: „Są już przecież objawy pojawienia się chorób bardzo niebezpiecznych i dawno niewidzianych w Europie: cholera na wyspach greckich, dezynteria w Wiedniu, różnego rodzaju pasożyty, pierwotniaki, które (...) nie są groźne w organizmach tych ludzi, mogą tutaj być groźne". ${ }^{22}$ Ta wypowiedź wkom-

${ }^{20}$ Portal TVN 24, http://www.tvn24.pl, [dostęp, 8.07.2016].

${ }^{21}$ Ibidem.

${ }^{22}$ Portal wpolityce, Kto przesadzit?, http://wpolityce.pl/polityka/268356-kto-przesadzil-kaczynski-imigranci-moga-przyniesc-nieznane-choroby-celinski-to-jezyk-nazizmu-mowilo-sie-ze -zydki-maja-tyfus, [dostęp 8.07.2016]. 
ponowuje się w proces sekurytyzacji tożsamości - tożsamości żałosnego innego, któremu należy współczuć, ale który też może stanowić potencjalne zagrożenie.

Sekurytyzacja jest jednak nie tylko procesem intersubiektywnej komunikacji, ale również procesem intertekstualnej komunikacji. Bezpieczeństwo nie musi być kreowane tylko werbalnie, ale również przez tekst, czy obraz. Odbiorca zaś rozumie dany przekaz niewerbalny w określonym kontekście. Poziom odbioru jest powiązany ze stopniem percepcji, która może być uzależniona od określonych skojarzeń czy odniesień emocjonalnych odbiorcy. Intertekstualność polega na tworzeniu swoistej siatki odniesień, w której funkcjonuje dany przekaz. Może on być warunkowany kulturowo i jest rozumiany w kontekście innych przekazów, z którymi jest powiązany. Poziom interpretacji zależy zatem od skojarzeń kulturowych, sytuacyjnych czy emocjonalnych. Ten sam obraz, np. łodzi po brzegi wypełnionej ludźmi może budzić skrajnie różne emocje i reakcje. Od współczucia, chęci niesienia pomocy, po złość, obawy, wypieranie. Przykładem pozytywnego odniesienia, może być nominacja mieszkańców wysp greckich do pokojowej Nagrody Nobla w 2016 r. ${ }^{23}$ Sekurytyzacja jest więc zależna od kontekstu, od specyfiki audytorium oraz od pozycji podmiotu sekurytyzacji. Tym samy należy podkreślić znaczenie siły performatywnej. Pisał o tym wspomniany wcześniej J. Austin, który podkreślał, że są pewne kategorie zdań, dla których nie da się ustalić prawdziwości. Zaliczył do nich zdania etyczne. Zwrócił również uwagę, że są takie wypowiedzi, które w sposób bezpośredni są czynami, stwarzają bowiem realne skutki, jak na przykład symboliczne „tak” w czasie zaślubin, kreuje określone realne skutki. ${ }^{24}$ Dla przykładu język ostatnio stosowany przez urzędników agencji FRONTEX, „ochrony Europy przed wrogiem”, skutkuje chociażby wzrostem budżetu tej agencji, który z 6 mln euro wzrósł do 90 mln euro obecnie. ${ }^{25}$

Powiązania pomiędzy bezpieczeństwem a migracją wydają się być oczywiste. $Z$ jednej strony, decyzja o opuszczeniu swojego państwa może wiązać się z zagwarantowaniem bezpieczeństwa, również kulturowego np. uchodźcy religijni (chrześcijanie) z Syrii. Z drugiej strony, zwiększenie różnorodności, etnicznej narodowej i religijnej, w państwie przyjmującym rodzi poczucie zagrożenia. Ponadto procesy migracyjne stawiają przed państwem określone wyzwania. Po pierwsze, dotykają problemu wolności i równości, wartości, z którymi utożsamiają się państwa europejskie. Po drugie, obecnego w części państw czy społeczeństw dążenia do ekskluzji, tych którzy nie są nami. W debacie politycznej i społecznej pojawia się również problem autonomii państw, ich suwerennej prerogatywy do kontrolowania wszelkich zjawisk zachodzących w granicach ich terytoriów oraz zdolności adaptowania się państw do procesów międzynarodowych, w tym rów-

${ }^{23}$ Greek islanders to be nominated for Nobel peace prize, The Guardian, https://www.theguardian.com/world/2016/jan/24/greek-islanders-to-be-nominated-nobel-peace-prize, [dostęp, 20.04.2017].

${ }^{24}$ Zob. J.L. Austin, Mówienie I poznawanie, PWN, Warszawa 1993.

${ }^{25}$ Der Spiegel, http://www.spiegel.de/international/europe/europe-tightens-borders-and-fails-to-protect-people-a-989502.html, [dostęp, 8.07.2016]. 
nież wdrażania działań i egzekwowania prawa. Warto przypomnieć wypowiedź premier Beaty Szydło w Sejmie, w trakcie debaty nad wotum nieufności wobec ministra obrony narodowej Antoniego Macierewicza. Słynne zapytanie,: „Dokąd zmierzacie, dokąd zmierzasz Europo? Powstań i obudź się z letargu, bo w przeciwnym razie będziesz opłakiwać swoje dzieci” oraz stwierdzenie ,zamach na całą Europę, zamach na cywilizację" nawiązywało do zamachu w Manchesterze w maju 2017 r. W sposób pośredni Pani premier powiązała kwestie migracji, kultury i bezpieczeństwa.

Bezpieczeństwo kulturowe należy utożsamiać z bezpieczeństwem tożsamościowym zarówno państwa, jak i grup społecznych czy jednostek. Źródłem tożsamości jest kultura, zatem bezpieczeństwo kulturowe to konieczność podejmowania działań w celu zapewnienia i stworzenia warunków, w jakich kultura będzie mogła się rozwijać i trwać. Należy jednak podkreślić, że definiowanie zagrożeń przez państwo i jego mieszkańców (nie wszystkich) nie musi być tożsame. Brak zagrożeń dla państwa nie oznacza, że takie zagrożenia nie są odczuwane przez mieszkańców. Jednocześnie to państwo, jego przywódcy, elity polityczne, mają ogromny wpływ na przedstawienia danego tematu w kategoriach bezpieczeństwa czy zagrożenia (o czym już wcześniej wspominałam). To pokazuje, że ontologiczny wymiar bezpieczeństwa kulturowego nie jest jednoznaczny. Jak bowiem ocenić sytuację w której muzułmanie domagają się odwołania w Niemczech święta jakim jest Oktoberfest. Petycja, Yousafa Mohhameda, mieszkańca Turcji z 2015 roku wzbudziła dużą dyskusję. Stwierdził on, że: „Oktoberfest to nietolerancyjne i antymuzułmańskie święto. Próbowaliśmy ignorować to wydarzenie, ale w jego trakcie dochodzi do zbyt wielu antymuzułmańskich incydentów, takich jak spożywanie alkoholu czy publiczne eksponowanie nagości”. W swojej petycji do władz Monachium pisał, że „Oktoberfest jest tradycyjnym niemieckim świętem, ale my, muzułmanie, nie możemy tolerować tego antyislamskiego wydarzenia, ponieważ obraża ono wszystkich muzułmanów". ${ }^{26}$ Jakież było zaskoczenie, gdy po pewnym czasie okazało się, że petycja była zwykły wybrykiem, żartem i po pewnym czasie została zdjęta z portalu change.org. Zdążyło ją jednak podpisać, czasami też dla żartu, ok. 500 osób. Nie zmienia to jednak faktu, że cała sytuacja wywołała niemałą dyskusją, oraz szereg komentarzy.

\section{PODMIOTY SEKURYTYZACJI}

W sekurytyzacji istotne jest zwrócenie uwagi na podmiot sekurytyzacji. Generalnie należy założyć, że zakres podmiotowy jest szeroki. Zatem każdy posiadający możliwości, kompetencje, chęci może stać się podmiotem sekurytyzacji,

${ }^{26}$ Portal wpolityce, Muzutmanin domaga się odowłania Oktoberfestu, http://wpolityce.pl/ swiat/265903-muzulmanin-domaga-sie-odwolania-oktoberfestu-obraza-uczucia-religijne-uchodzcow [dostęp,18.04.2017]. 
chociaż najczęściej, w ujęciu szkoły kopenhaskiej, możliwościami takimi dysponuje państwo. Siłę performatywną posiada głowa państwa, podobnie jak inni politycy partii sprawujących władzę oraz opozycyjnych, o czym już wcześniej wspominałam.

Warto zwrócić uwagę na kampanię prezydencką we Francji w 2017 r., w trakcie której kandydatka na urząd prezydenta Marie Le Pen w swoich wystąpieniach, wielokrotnie poruszała temat imigracji. Tym samym zapewniała, że jako prezydent podejmie z nią walką oraz z krępującymi więzami UE. Tym samym oskarżała kontrkandydatów Francoisa Fillona i Emmanulela Macrona o akceptację imigracji i tolerancję wobec islamizmu i dżihadyzmu. ${ }^{27} \mathrm{~W}$ Niemczech, w których partie skrajnie prawicowe przez długi czas nie odgrywały istotnej roli, zyskują teraz popularność, odwołując się do antyimigranckich sentymentów. Wśród nich Alternatywa dla Niemiec (AfD) odnotowująca rekordowe poparcie. Przewodniczący AfD w Brandenburgii Alexander Gauland zarzucił władzom w Berlinie 'moralny imperializm' wobec innych państw Unii Europejskiej. Polityk AfD porównywał sytuację obecną do schyłkowego okresu Cesarstwa Rzymskiego „,najechanego przez hordy barbarzyńców". ${ }^{28}$ Coraz aktywniejszy jest również ruch społeczny Pegida, utożsamiany z działaniami przeciw imigrantom i uchodźcom. Przywódca Pegidy Lutz Bachmann w jednym z wystąpień stwierdził, że rząd w Berlinie otwierając granice dla imigrantów ,prowadzi Europę w kierunku wojny domowej”. ${ }^{29}$

W narrację sekurytyzacji wpisuje się także publikacja autorstwa Thilo Sarrezina z 2010 r. (od 2009 do września 2010 roku członek zarządu Banku Centralnego Republiki Federalnej Niemiec) zatytułowana „Niemcy likwidują się same. Jak wystawiamy nasz kraj na ryzyko" (tytuł niemiecki "Deutschland schafft sich ab: Wie wir unser Land aufs Spiel set zen"). Autor zarzuca w niej imigrantom brak chęci do integracji, a także to, że tworzą „,społeczeństwa równoległe”. T. Sarrazin ocenił, że każde pokolenie Niemców jest mniejsze niż poprzednie. Według niego w ponad 1000-letniej historii naród niemiecki jest - czysto ilościowo - na drodze do samolikwidacji. Tym samym w jego ocenie, społeczeństwo przechodzi poważne jakościowe (kulturowe) przemiany. Podkreśla, że imigracja koncentrowała się w minionych dziesięcioleciach w większym stopniu na niewykształconych warstwach z państw ukształtowanych przez islam. W jego ocenie zagrożenie stanowią głównie imigranci z państw islamskich, a nie z Azji czy Europy Wschodniej. ${ }^{30}$ Publikacja wywołała dyskusję, w której coraz częściej politycznie artykułowana

${ }^{27}$ Portal Polonia Christiana, http://www.pch24.pl/marine-le-pen-gotowa-na-walke-z-potopem -imigracji--mowi--ze-wydobedzie-francje-z-wiezienia-ue,50964,i.html, [dostęp, 18.04.2017].

${ }^{28}$ Portal niemcy-online, http://www.niemcy-online.pl/wydarzenia/komentarze/bunt-przeciw -azylantom-1040, [dostęp, 8.07.2016].

${ }^{29}$ Portal Telewizja Republika, http://telewizjarepublika.pl/rzad-prowadzi-europe-w-kierunku-wojny-domowej-szubienica-dla-merkel-na-antyimigranckim-wiecu-w-dreznie, 24757.html, [8.07.2016].

${ }^{30}$ Portal Newsweek, http://swiat.newsweek.pl/napisal-ksiazke--moze-stracic-stanowisko,63806,1,1.html, [dostęp, 8.07.2016]. 
jest teza o końcu, a raczej niepowodzeniu polityki wielokulturowości. Przyczyną tych problemów nie jest pochodzenie etniczne, ale pochodzenie z islamskiego kręgu kulturowego. Bowiem kultura tych imigrantów ukształtowała ich w sposób, który nie da się pogodzić ze stylem życia i kulturowymi wartościami świeckiego społeczeństwa.

Skrajne partie zyskały również dużą popularność w Grecji, gdzie neonazistowski Złoty Świt we wrześniowych wyborach (2015) otrzymał trzecią lokatę. Nadal dużym poparciem we Włoszech cieszy się ksenofobiczna Liga Północna. W Holandii na coraz większe poparcie może liczyć narodowo-liberalna Partia Wolności ${ }^{31}$, której lider Geert Wielders, od kilku lat bazuje na sentymentach antymuzułmańskich. W swoim programie odwołuje się do tożsamości kulturowej i religijnej oraz wskazuje na zależności między zagrożeniem tej tożsamości a napływem imigrantów. Jest znany z podżegania do dyskryminacji i nienawiści. Za swoje wypowiedzi dwukrotnie stanął przed sądem. Pierwszy raz w 2011 roku. Wówczas sąd oceniał, czy zgodne z prawem jest nazywanie islamu religią przemocy, porównanie Koranu do „Mein Kampf” Adolfa Hitlera i nawoływanie do odbierania obywatelstwa „muzułmańskim kryminalistom”. Decyzją sądu G. Wilders został wówczas uniewinniony. Kolejny raz stanął przed sądem wiosną 2016 r. za nawoływanie do dyskryminacji. Powodem były jego komentarze wygłaszane pod adresem Marokańczyków podczas wystąpienia w Hadze po wyborach lokalnych w 2014 roku. Transmisja wypowiedzi, a przede wszystkim pytanie G. Wildersa do zwolenników: „Czy chcecie w swoim mieście mniej czy więcej Marokańczyków. Na odpowiedź „mniej” zapewnił: „zajmiemy się tym”, co wywołało liczne protesty. ${ }^{32}$ Kampanię wyborczą wiosną 2017 roku prowadził, głównie korzystając z komórki i mediów społecznościowych. Tematem przewodnim było odwoływanie się do tożsamości radykalnego innego. Chociaż kwestie migracji były też poruszane przez premiera Marka Rutte, przywódcy Partii Ludowej na rzecz Wolności i Demokracji (VVD), który stwierdził w jednym ze swoich wystąpień, że ,jeżeli ktoś nie chce żyć w Holandii i stosować się do jej praw, to powinien wyjechać". ${ }^{33}$ Być może takie wystąpienia przysporzyły mu więcej głosów co w konsekwencji zagwarantował zwycięstwo w marcowych wyborach 2017 roku, podobnie jak twarda polityka wobec Turcji. Te wybory stały się swoistym preludium do mających obyć się wyborów prezydenckich we Francji (kwiecień 2017) i wyborów parlamentarnych w Niemczech (wrzesień 2017). Gdzie partie antyemigracyjne liczą na dobre wyniki. Wyniki w Holandii pokazują, że tematyka imigracji jest nadal aktualna w debacie politycznej.

${ }^{31}$ W wyborach parlamentarnych 2017 r. Partia Wolności zdobyła 20 mandatów o 5 więcej niż w poprzednich wyborach.

${ }^{32}$ Portal rp.pl, http://www.rp.pl/Unia-Europejska/303189909-Co-mozna-powiedziec-o-imigrantach-Proces-Geerta-Wildersa.html\#ap-2, [dostęp, 8.07.2016].

${ }_{33}$ Portal Interia, fakty, http://fakty.interia.pl/swiat/news-wybory-w-holandii-2017-geert-wilders-straszak-na-migrantow-c,nId,2368567 [dostęp, 20.04.2017]. 
W Polsce w Sejmie w trakcie nadzwyczajnego posiedzenia w sprawie uchodźców we wrześniu 2015 r. Jarosław Kaczyński stwierdził: „ważne jest pytanie: czy rząd ma prawo - pod obcym, zewnętrznym naciskiem, bez wyrażonej zgody narodu - podejmować decyzje, które z wysokim stopniem prawdopodobieństwa mogą mieć negatywny wpływ na nasze życie, naszą codzienność, nasze życie publiczne, przestrzeń publiczną, na naszą realną sferę wolności, wreszcie na nasze bezpieczeństwo” i dalej: „Chcę powiedzieć jasno: Prawo i Sprawiedliwość uważa, że rząd nie ma prawa podejmowania takich decyzji. Co więcej uważa, że podejmowanie takich decyzji bez wyraźnej zgody społeczeństwa jest łamaniem Konstytucji, łamaniem praw suwerenności narodu i łamaniem praw obywatelskich. Dlatego nie ma tutaj naszej zgody". ${ }^{34}$ Tym samym podkreślał, że „nie chodzi o przyjęcie tej czy innej liczby cudzoziemców, tylko o to, że (według J. Kaczyńskiego) istnieje poważne niebezpieczeństwo, że zostanie uruchomiony pewien proces, który skrótowo można opisać tak, że najpierw liczba cudzoziemców gwałtownie się zwiększy, następnie nie będą oni przestrzegać naszego prawa i naszych obyczajów, i równolegle będą narzucać, w agresywny sposób, w przestrzeni publicznej swoją wrażliwość i swoje wymogi w różnych dziedzinach życia. ${ }^{35}$ Podawał również przykłady z państw, w których znajdują się liczne środowiska imigrantów. Powoływał się na sytuację w Szwecji, gdzie, jak stwierdził „są już obawy przed wywieszaniem flag narodowych na budynkach szkół”. Tym samym pytał: „Czy chcecie państwo, żeby to pojawiło się także w Polsce, żebyśmy przestali być gospodarzami we własnym kraju? Polacy tego nie chcą i nie chce tego PiS". ${ }^{36}$

W Wielkiej Brytanii na fali wydarzeń związanych z utworzeniem w Iraku i Syrii islamskiego kalifatu, premier David Cameron we wrześniu 2014 r. stwierdził, że istnieje poważne zagrożenie dalszego eksport terroryzmu. Tym bardziej, że jak podkreślił, przytaczając dane opublikowane przez niezależnych ekspertów, co najmniej 500 osób z Wielkiej Brytanii wyjechało, aby brać udział w walkach w Syrii i Iraku po stronie dżihadystów. Stwierdził również, że „należy być świadomym zagrożenia jakim jest radykalizacja, za sprawą rozprzestrzeniania się zjadliwej, jak to określił, ideologii islamskiego ekstremizmu, który wierzy, że dzięki brutalizacji działań terrorystycznych zmusi innych do zaakceptowania ich wypaczonego poglądu na świat i powrót do średniowiecza". ${ }^{37}$ Proces sekurytyzacji widoczny był również w kontekście imigracji z innych państw UE w tym z Polski. D. Cameron w 2013 r. stwierdzi: „Uważam, że powinniśmy wyciągnąć wnioski z historii. Myślę, że błąd popełnił poprzedni rząd, dając nieograniczony, natychmiastowy dostęp do brytyjskiego rynku pracy Polsce, Węgrom i państwom

\footnotetext{
${ }^{34}$ Portal TVN24, http://www.tvn24.pl, [dostęp, 20,04.2017].

${ }^{35}$ Ibidem.

${ }^{36}$ Ibidem.

${ }^{37}$ Portal gov.uk, https://www.gov.uk/government/speeches/pm-statement-on-european-council-and-tackling-extremism, [dostęp, 10.08.2014].
} 
bałtyckim”. Jego zdaniem „trzeba zrobić wszystko, by zatrzymać 'masową migrację' ze Wschodu". ${ }^{38}$ Tym samym budował swoje poparcie na nastrojach antyimigracyjnych, których finał miał miejsce w czerwcu 2016 r. w wyniku referendum. Takiego scenariusza, chyba nie przewidział nawet jego autor.

Również istotna rola przypada podmiotom niepaństwowym. Duże znaczenie w procesie sekurytyzacji mogą odgrywać media: prasa, radio, telewizja, media społeczne, czy organizacje pozarządowe oraz think thanki. W informacjach prasowych, telewizyjnych czy zamieszczanych na portalach internetowych, wykorzystuje się statystyki, które kreują obraz współczesnej Europy, nie „,sterylnej” i wolnej od innych, obcych kulturowo, religijnie, etnicznie. „Inni” są przedstawiani w mediach jako ci, którzy dokonują ,inwazji”, „zdobywają” Europę na łodziach (boat people) czy w kontenerach samochodowych.

Istota rola w procesie sekurytyzacji może też przypaść osobistościom ze świata kultury czy religii. Dlatego chętnie wykorzystuje się przekaz kulturowy, np.: film, muzykę, żarty, rysunki, plakaty. Mamy również do czynienia z wizualizacją tragizmu, co ma istotne znaczenie w kreowaniu dyskursu na temat tzw. kryzysu migracyjnego. Ludzie kultury włączają się w dyskusję z perspektywy sztuki i sfery audiowizualnej. Zatem kultura może odgrywać istotną rolę zarówno w procesie sekurytyzacji, jak i desekurytyzacji. Czyli procesu odwrotnego, polegającego na niewłączaniu, czy przenoszeniu tematów do kategorii tzw. „,normalnej polityki”. Warto w tym miejscu podkreślić wagę autorytetów moralnych. Jednym z nich jest papież Franciszek, który w swoich wypowiedziach o imigrantach mówi jako o „braciach i siostrach”, co staje w sprzeczności wypowiedzi niektórych polskich środowisk kościelnych.

Tematem filmu jest zarówno ukazanie trudności integracyjnych mniejszości muzułmańskich i tego jakie rodzi to konsekwencje (np. „Almanya. Witajcie w Niemczech" - (Almanya - Willkomen in Dautchland), reż. Yasemin Samdereki, 2011). Może też służyć wzmacnianiu stereotypów i umacniać wizję Europy jako oblężonej twierdzy, czego przykładem był film „Bitwa pod Wiedniem” (reż. Renzo Martinelli, 2012 r.). Można też w nieco w krzywym zwierciadle ukazać aspiracje do bycia terrorystą oraz niezdolność w gruncie rzeczy państwa do skutecznej obrony (film „Cztery lwy” - (Four Lions), reż. Christopher Morris, 2010).

Innym przykładem jest znana sprawa „karykatur duńskich”. W 2005 roku duńska gazeta „Jyllands-Posten” opublikowała karykatury proroka Mahometa. Rysunkom tym nie można odmówić siły performatywnej. Karykatury nie tylko ukazują w obraźliwy sposób proroka. Istotne jak to robią. Ukazują Mahometa w sposób pejoratywny, z bombą i zapalonym lontem w turbanie, co ma przełożenie na całą społeczność muzułmańską i utożsamianie jej z terrorystami. W konsekwencji prowadzi to do konstruowania określonej tożsamości jako zagrożenia

${ }^{38}$ Portal na: Temat, http://natemat.pl/86193,cameron-o-otwarciu-rynku-pracy-dla-polakow -to-byla-wielka-pomylka-przez-polskich-imigrantow-londyn-nie-chce-rozszerzenia-ue, [dostęp, 8.07.2016]. 
- radykalnego 'innego'. Oczywiście w tym kontekście nasuwa się również pytanie o wolność słowa, poprawność polityczną i granice, których przekroczenie będzie równoznaczne z profanacją.

$\mathrm{W}$ proces sekurytyzacji islamu w Europie wkomponowuje się neologizm polityczny „Eurabia”, który skutecznie służy sugerowaniu opanowania Europy przez islam. W tym duchu wypowiadały się: znana dziennikarka włoska Oriana Fallaci na łamach prasy i w swojej książce „Siła rozumu” (La forza della ragione, 2004), czy Melanie Phillips w książce „Londonistan. Jak Wielka Brytania stworzyła państwo terroru" (Londonistan. How Britain is Creating a Terror State Within, 2006). Były to głosy w dyskusji wokół wielokulturowości, która ich zdaniem skończyła się porażką. Zasadniczym argumentem za tą tezą jest według $\mathrm{M}$. Phillips fakt, że zamachów w 2005 r roku dokonali nie obcy, ale osoby urodzone i wykształcone w Wielkiej Brytanii. Kolejnym głosem jest książka Bruce'a Bawera „Kiedy Europa spała” (While Europe Slept. How radical Islam is Destroying the West from Within, 2006), w której zwraca uwagę na zagrożenie demograficzne i kulturowe dla Europy ze strony islamskich imigrantów, czemu sprzyja bierność rządów państw europejskich. Ten sam ton pojawia się w tekście opublikowanym w „The Economist” w czerwcu 2006 r. - „Eurabia. Mit i rzeczywistość islamu w Europie" (Eurabia. The myth and rality of Isalm in Europe). W dzień zamachu na redakcję ‘Charlie Hebdo' w Paryżu, ukazuje się książka Michela Houellebecqa, „Uległość”. Powieść futurystyczna, political fiction, która również wkomponowuje się w debatę i proces sekurytyzacji islamu, podobnie jak książka Marcina Wolskiego „Eurodżihad”.

Nie sposób nie wspomnieć też kampanii przedreferendalnej w Szwajcarii w 2010 roku w sprawie zakazu budowy minaretów. Na plakatach towarzyszących kampanii minarety były przedstawiane jako rakiety, umieszczone na fladze Szwajcarii. Na wielu z nich pojawiała się też postać okryta czarnym nikabem, co w podtekście ma również wymiar pejoratywny, budzi poczucie zagrożenia.

Muzycy, aktorzy, uczestnicy programów rozrywkowych, gwiazdy mediów społecznościowych za sprawą swojej popularności mogą wywierać wpływ na decydentów politycznych oraz na opinię publiczną. Tym samym należy podkreślić, że zaangażowanie ludzi kultury oraz celebrytów w działania na rzecz rozwiązywania problemów społecznych jest bardzo pożądane i akceptowane (działalność aktorki Angeliny Jolie i jej współpraca z UNHCR). Problem uchodźców docierających do Europy został dostrzeżony w filmie w reżyserii Gianfranco Rosi pt. „Fuocoammare. Ogień na morzu”, który zdobył główną nagrodę na festiwalu filmowym Berlinale w 2016 r. Ponadto zdobył Europejską Nagrodę Filmową dla najlepszego filmu dokumentalnego i był nominowany do Oscara za najlepszy pełnometrażowy film dokumentalny. Film ukazuje dwa równolegle światy: ludności zamieszkującej wyspę Lampendusa na Morzu Śródziemnym oraz cudzoziemców poszukujących schronienia w Europie za wszelką cenę. Twórcom udało się pokazać pierwsze minuty po dotarciu służb ratunkowych do łodzi. Widzowie na wielkim ekranie mogli ujrzeć przerażające warunki, jakie panowały na łodziach 
przepełnionych migrantami. Film jednak nie spotkał się ze szczególnym zainteresowaniem widzów. W Polsce obraz wyświetlany był przez krótki czas jedynie w kilkunastu kinach studyjnych. ${ }^{39}$

Exodus został również uwieczniony na licznych fotografiach. Prace fotografów zostały docenione przez World Press Photo. Dziesięć zdjęć nagrodzono w najważniejszych kategoriach. Zaś czarno-białe zapisy ludzkich tragedii na prowizorycznych łodziach czy prób przedostania się przez kolczaste ogrodzenie na Węgrzech pokazują codzienność cudzoziemców w drodze do Europy. Wykonane zdjęcia dopowiadają historię współczesnych migracji, które wypełniają karty historii współczesnego świata ${ }^{40}$ Tematyka migracji jest również widoczna w popkulturze. W Polsce do popularnego serialu „Barwy szczęścia”, został ostatnio włączony wątek imigranta/uchodźcy, rodziny syryjskiej poszukującej schronienia w Polsce. Jest to bez wątpienia próba przełamywania stereotypów czy uprzedzeń, ale również zwrócenie uwagi na konieczność zrozumienia różnic kulturowych. Oczywiście należy sobie postawić pytanie na ile działania te będą skuteczne w procesie desekurytyzacji, i czemu służą - czy jedynie lepszemu samopoczuciu ich twórców?

\section{SKUTECZNOŚĆ SEKURYTYZACJI}

Sekurytyzacja może zostać zainicjowana zarówno na poziomie państwowym, np. przez rząd czy agendy rządowe. Oraz na poziomie niepaństwowym. Rząd może również wspierać proces sekurytyzacji, który został zainicjowany przez podmioty niepaństwowe. Oczywiście o skuteczności sekurytyzacji świadczy przekonanie innych o istniejącym zagrożeniu. Uzyskanie takiej akceptacji służy legitymizacji późniejszych działań w tym tych nadzwyczajnych.

Według badań przeprowadzonych przez Pew Research Center w czerwcu 2016 roku w Europie generalnie coraz mniej pozytywnie ocenia się różnorodność kulturową. W dziesięciu z badanych państw występowało przekonanie, że wielokulturowość będąca skutkiem imigracji nie będzie miała pozytywnych skutków. W tym tylko ok. jedna trzecia respondentów w Szwecji (36\%), Wielkiej Brytanii (33\%) i Hiszpanii (31\%) opisuje rosnąca różnorodność rasową, etniczną i narodową, w korzystnym świetle. Natomiast ponad połowa respondentów w Grecji (63\%) i we Włoszech (53\%) twierdzi, że rosnąca różnorodność sprawia, że ich państwa stają się gorszym miejscem do życia. Podobnie negatywne opinie wygłasza 41\% Węgrów i 40\% Polaków. ${ }^{41}$ W Wielkiej Brytanii, według badań Instytutu

${ }^{39}$ K. Matuszczyk, Sztuka nie zna granic, czyli kryzys uchodźczy w sferze audiowizualnej, Biuletyn Migracyjny 2017, marzec, http://biuletynmigracyjny.uw.edu.pl/56-marzec-2017/sztukanie-zna-granic-czyli-kryzys-uchodzczy-w-sferze-audiowizualnej, [dostęp, 20.04.2017].

${ }^{40}$ Ibidem.

${ }^{41}$ In views of diversity, many Europeans are less positive than Americans, http://www.pewresearch.org/fact-tank/2016/07/12/in-views-of-diversity-many-europeans-are-less-positive-than-americans/, [dostęp, 8.07.2016]. 
Gallupa, w 2015 r. najważniejszym tematem który niepokoił Brytyjczyków była imigracja, przed gospodarką, zdrowiem, bezrobociem, biedą, czy terroryzmem. ${ }^{42}$ Brytyjczycy tym samym wyprzedzili Amerykanów, dla których problem imigracji znajdował się na czwartym miejscu.

Niechęć wobec imigracji spoza UE potwierdzają również wyniki Eurobarometru z 2014 r. Aż u 57\% respondentów obecność imigrantów spoza UE wzbudzała negatywne emocje. ${ }^{43}$ Warto zaznaczyć, że jeszcze w 2010 r. w badaniach Eurobarometru na pytanie, czy migracja będzie pozytywnie wpływała na wzrost tolerancji, aż 50\% respondentów wypowiadało się pozytywnie. ${ }^{44}$ Większość też w dłuższej perspektywie wyrażała przekonanie, że w przyszłości Europa będzie jeszcze bardziej tolerancyjna i otwarta dla mniejszości etnicznych, narodowych, czy religijnych. Jak się jednak okazuje, były to bardziej deklaracje, które w konfrontacji z rzeczywistością, nie wytrzymały próby czasu.

W badaniach Ipsos dla Międzynarodowej Organizacji ds. Migracji przeprowadzonych w Polsce we wrześniu 2016 r. ocena zagrożenia, jakie mogą stanowić dla Polski poszczególne narodowości w większości przypadków utrzymuje się na stosunkowo niskim poziomie. Według badań w ciągu ostatniego roku wyraźnie spadły obawy w stosunku do Ukraińców (z 35 do 30\%), ale wzrosły w stosunku do Arabów (do 69\%), Afrykanów (do 24\%), a także mieszkańców Europy Zachodniej (z 19 do 25\%). ${ }^{45}$ Niemniej jednak blisko 2/3 respondentów ma pewne obawy związane z napływem cudzoziemców do Polski, niezależnie od tego, czy mieli oni kontakt z cudzoziemcami w ciągu ostatnich 12 miesięcy, czy nie. 6 na 10 respondentów uważa, że cudzoziemcy stanowią zagrożenie dla państwa Nieco ponad $80 \%$ z nich twierdzi, że zagrażają oni bezpieczeństwu. Co trzecia osoba uważa, że stanowią zagrożenie dla rynku pracy. Jak wynika z badań, obawy przed napływem cudzoziemców częściej prezentują osoby, które opierają swoją wiedzę na informacjach pochodzących z mediów oraz od innych osób. Niemniej jednak ich poziom jest najwyższy w grupie wiekowej powyżej 60 lat.

Czy cudzoziemcy mogę mieć negatywny wpływ na kulturę Polski? Większość badanych miało mało zdecydowany pogląd. Z jednej strony, jak wskazują badania, osobisty kontakt z cudzoziemcami sprzyjał bardziej pozytywnej ocenie tego wpływu. Z drugiej strony, opinie o wpływie cudzoziemców na polską kulturę uległy w ciągu ostatniego roku wyraźnemu przesunięciu w kierunku negatywnym. 23\% respondentów ocenia ich wpływ na kulturę Polski jako zdecydowanie negatywny

${ }^{42}$ Zob. The Economist, http://www.economist.com/blogs/graphicdetail/2016/01/public-opinion-and-immigration, [dostęp, 8.07.2016].

${ }^{43}$ Standard Eurobarometer 82, Autumn 2014, Public Opinion in the European Union, http:// ec.europa.eu/public_opinion/archives/eb/eb82/eb82_first_en.pdf, [dostęp, 8.07.2016].

${ }^{44}$ Standard Eurobarometr 71, „Future of Europe”, January 2010, http://ec.europa.eu/public_opinion/archives/eb/eb71/eb713_future_europe.pdf, [dostęp, 8.07.2016].

${ }^{45}$ Badanie na temat postaw wobec cudzoziemców w Polsce Ipsos dla IOM, Warszawa, wrzesień 2016, https://poland.iom.int/sites/default/files/IOM_Cudzoziemcy_raport_IX_2016.pdf [dostęp, 20.04.2017]. 
(1-3 na skali 10-stopniowej), a 9\% jako zdecydowanie pozytywny (oceny 8-10). ${ }^{46}$ Można zatem stwierdzić, że lęk wzbudza odmienność kulturowa i religijna przybyszów oraz możliwe problemy z integracją. Te lęki zaś mogą przekładać się na działania sekurytyzacyjne realizowane przez państwa. O skuteczności sekurytyzacji świadczą powyższe badania opinii publicznej oraz sukcesy wyborcze partii, które w dużej mierze swój kapitał polityczny budują na nastrojach antyimigracyjnych.

\title{
WNIOSKI
}

Wyniki przeprowadzonych w ostatnim czasie badań wskazują, że coraz większa część społeczeństwa Europy jest podatna na określony typ narracji. Nic dziwnego, że w poglądach Europejczyków wobec imigrantów jest wiele ambiwalencji. Spotykamy się z jednej strony, z podejściem współczującym - tak współczujemy Wam, ale Wam nie ufamy. Współczujemy Wam, ale lepiej zostańcie jak najdalej od nas. $Z$ drugiej zaś, z podejściem opartym na poczuciu zagrożenia - Nie chcemy Was u siebie. Ba nawet zapłacimy innym - Turcji - abyście zostali u nich. Napływ imigrantów bez wątpienia stanowi dla państwa, jego instytucji i społeczeństwa wyzwanie. Jednak czy imigracja będzie traktowana jako zagrożenie egzystencjalne - sekurytyzacja, czy raczej jako problem, którym powinna się zająć „normalna" polityka - desekurytyzacja, zależy od wielu uwarunkowań. Skuteczność sekurytyzacji zależy od wrażliwości i podatności społeczeństwa na określony typ narracji, ale również siły pozycjonalnej i performatywnej podmiotów sekurytyzacji. Pozwala odpowiedzieć na pytanie czego się boimy, gdzie widzimy zagrożenia. Może też być impulsem do przyjmowania strategii, wypracowania rozwiązań systemowych, które osłabią obawy i pokażą, że różnorodność kulturowa nie musi być źródłem zagrożeń, ale źródłem inspiracji.

Title: Securitization of Migration in European Cultural Security

\begin{abstract}
Securitization is an intersubjective and intertextual process of incorporating specific topics into the security sphere. It is defined as an act of speech, based on the premise that language can not only convey information, but also create social facts. Incorporating specific topics into the security realm by the securitization process demonstrates that reality is a social construct in which language and image play an important role. In Europe, the fear of 'others' is growing. It is a consequence of the dynamic and unprecedented scale of human flows. This threat is also a consequence of the effective securitization of migration process. In the political and social debate more and more questions are emerging about the future of Europe. How will migratory processes change the cultural face of Europe? Does immigration endanger the cultural identity of Europe?
\end{abstract}

Key words: migration, migration crisis in Europe, securitization, desecuritization

${ }^{46}$ Ibidem. 